\title{
Inhaled iloprost improves gas exchange in patients with COVID-19 and acute respiratory distress syndrome
}

\author{
Natalia A. Tsareva', Sergey N. Avdeev ${ }^{1 *} \mathbb{B}$, Djuro Kosanovic ${ }^{1}$, Ralph Theo Schermuly ${ }^{2}$, Natalia V. Trushenko ${ }^{1}$ and \\ Galina V. Nekludova ${ }^{1}$
}

Keywords: Iloprost, Inhalation, SARS-CoV-2, COVID-19, Acute respiratory distress syndrome

\section{To the Editor,}

Severe acute respiratory syndrome coronavirus (SARS$\mathrm{CoV})-2$ outbreak that began in 2019 and spread rapidly across the world has been demonstrated to cause viral pneumonia, acute respiratory distress syndrome (ARDS) and multi-organ system failure [1]. Given the lack of scientific data, efforts are focused on an empirical search for therapeutic strategies to ensure the adequate gas exchange, including methods that can be applied in intensive care unit (ICU) setting. Iloprost is a synthetic analogue of prostacyclin and recent studies investigated its efficacy when applied via infusion in the context of COVID-19 [2, 3]. In addition, inhaled iloprost is a wellknown option for the treatment of pulmonary hypertension $(\mathrm{PH})$ [4]. Therefore, in the current study we have analyzed the effects of inhaled iloprost on gas exchange in patients with COVID-19 associated ARDS.

This case-control study was conducted in the Pulmonology Department of university-affiliated hospital (Sechenov University) between April 8, 2020, and May 20,2020 . The study was approved by the local ethics committee of Sechenov University, and written informed consent was obtained from all patients. Eligible patients were subjects aged over 18 years with SARS-CoV-2 infection

\footnotetext{
*Correspondence: serg_avdeev@list.ru

${ }^{1}$ Department of Pulmonology, I.M. Sechenov First Moscow State

Medical University (Sechenov University), Healthcare Ministry of Russia,

Trubetskaya Street 8, Moscow, Russia 119991

Full list of author information is available at the end of the article
}

confirmed by real-time PCR and ARDS according to the Berlin definition [5] and $\mathrm{PaO}_{2} / \mathrm{FiO}_{2} \leq 200 \mathrm{mmHg}$. The exclusion criteria considered need for immediate endotracheal intubation and unstable hemodynamics. The primary objective was to assess the effect of inhaled iloprost on $\mathrm{PaO}_{2} / \mathrm{FiO}_{2}$ in patients with ARDS on Day 5 . Iloprost was administered with a vibrating mesh nebulizer (Aeroneb Solo; Aerogen) four times per day (20 $\mu \mathrm{g}$ per administration) for 5 days. The control patients were selected based on the same enrollment criteria and we have prospectively recorded the measured parameters on the same data chart. The matching of the controls and patients treated with iloprost was performed based on the following criteria: age (within \pm 5 years); National Early Warning Score (NEWS)-2 score on admission (within \pm 1 points) and $\mathrm{PaO}_{2} / \mathrm{FiO}_{2}$ on admission (within $\pm 20 \mathrm{mmHg}$ ). Computed tomography (CT) scan was performed and CT severity score was calculated as 5-point scale according to the degree of lung involvement: (0) no involvement, (1) less than $25 \%$, (2) $25-50 \%$, (3) $50-75 \%$ and (4) more than 75\% [6]. All adverse events (AE) and serious AE possibly related to inhaled iloprost were documented.

Twenty-three consecutive patients received at least one iloprost inhalation and 22 patients were included into the control group. The baseline demographic, clinical and laboratory characteristics did not differ significantly between the groups (Table 1). Time between the symptom onset and iloprost administration was $8.0 \pm 0.5$ days. On day 5, iloprost therapy led original author(s) and the source, provide a link to the Creative Commons licence, and indicate if changes were made. The images or other third party material in this article are included in the article's Creative Commons licence, unless indicated otherwise in a credit line to the material. If material is not included in the article's Creative Commons licence and your intended use is not permitted by statutory regulation or exceeds the permitted use, you will need to obtain permission directly from the copyright holder. To view a copy of this licence, visit http://creativecommons.org/licenses/by/4.0/. The Creative Commons Public Domain Dedication waiver (http://creativeco mmons.org/publicdomain/zero/1.0/) applies to the data made available in this article, unless otherwise stated in a credit line to the data. 
Table 1 Baseline characteristics of the study population

Iloprost $(n=23)$

Control $(n=22)$

Demographic variables

Age, years

$62(53-68)$

$15(65.2)$

Male, $n$ (\%)

Caucasian, $n(\%)$

Anthropometric measures and risk factors

Smokers, n (\%)

BMl, $\mathrm{kg} / \mathrm{m}^{2}$

Medical history

Cardiovascular disease, $n$ (\%)

Chronic lung disease, $n(\%)$

Diabetes mellitus, $n$ (\%)

Chronic kidney disease, $n$ (\%)

Clinical variables

Cough, $n(\%)$

Dyspnea, $n$ (\%)

Fever, $n$ (\%)

Borg dyspnea scale

Laboratory tests

WBC, $10^{9} / \mathrm{L}$

C-reactive protein, $\mathrm{mg} / \mathrm{L}$

D-dimer, $\mu \mathrm{g} / \mathrm{mL}$

Blood gases

$\mathrm{PaO}_{2}, \mathrm{mmHg}$

$\mathrm{PaCO}_{2}, \mathrm{mmHg}$

$\mathrm{SpO}_{2}, \%$

$\mathrm{PaO}_{2} / \mathrm{FiO}_{2}, \mathrm{mmHg}$

Computed tomography

CT severity scale, $0 / 1 / 2 / 3 / 4, n$ (\%)

Medications

Vasopressors, $n$ (\%)

Corticosteroids, $n$ (\%)

Hydroxychloroquine, $n$ (\%)

Azithromycin, $n$ (\%)

Respiratory support

Supplemental oxygen, $n$ (\%)

CPAP, $n$ (\%)
$23(100)$

8 (34.8)

$31.0(28.0-34.8)$

8 (34.8)

$0(0)$

$6(26.1)$

$3(13.0)$

$21(91.3)$

$21(91.3)$

19 (82.6)

$6(5-8)$

$5.9(5.1-8.8)$

131 (102-190)

$2.9(1.9-3.8)$

$65.8(55.1-78.1)$

$32.0(29.2-35.0)$

89 (88-90)

$131(120-138)$

0 (0)/0 (0)/7 (30.4)/9 (39.1)/7 (30.4)

$0(0)$

$15(65.2)$

21 (91.3)

$21(91.3)$

$16(69.6)$

7 (30.4)
$60(54-69)$

17 (77.3)

22 (100)

$10(45.5)$

$32.0(26.5-39.6)$

$9(40.9)$

1 (4.5)

$7(31.8)$

1 (4.5)

21 (95.4)

19 (86.4)

18 (81.8)

$5(2-8)$

$6.8(5.2-8.3)$

$128(89-186)$

$3.5(1.9-4.6)$

$62.0(49.0-77.7)$

$28.8(23.8-32.7)$

90 (87-93)

130 (114-168)

$0(0) / 0(0) / 5$

$(22.7) / 14$

(63.6)/3 (13.6)

$0(0)$

$17(77.3)$

$19(86.4)$

19 (86.4)

14 (63.6)

$8(36.4)$

Data are expressed as absolute values (\%) or median (interquartile range)

$\mathrm{BMI}$ body mass index, $W B C$ white blood cells, $\mathrm{PaO}_{2}$ arterial oxygen tension, $\mathrm{PaCO}_{2}$ arterial carbon dioxide tension, $\mathrm{SpO}_{2}$ oxygen saturation, FiO $\mathrm{fraction}$ of inspired oxygen, $C T$ computed tomography, CPAP continuous positive airway pressure

to the significant improvement in $\mathrm{SpO}_{2} / \mathrm{FiO}_{2}$ and $\mathrm{PaO}_{2} /$ $\mathrm{FiO}_{2}$ compared to the baseline and controls (Fig. 1). There was also a significant reduction of the Borg dyspnea score ( 6 vs. $4, p=0.01$ ). Three patients in iloprost group and 6 patients in control group were transferred to ICU due to rapidly progressive respiratory failure. Remaining patients were free of supplemental oxygen/continuous positive airway pressure at the end of follow-up. The overall iloprost safety profile was similar to that observed in previous studies. The most common AE were flushing $(n=5 ; 21.7 \%)$ and jaw pain $(n=3$; $13.0 \%)$. There were no cases of AE-related iloprost discontinuation.

In the context of COVID-19, still limited literature sources highlighted the usage of iloprost as potential therapeutic option $[2,3]$. In the line with the literature, 
a)

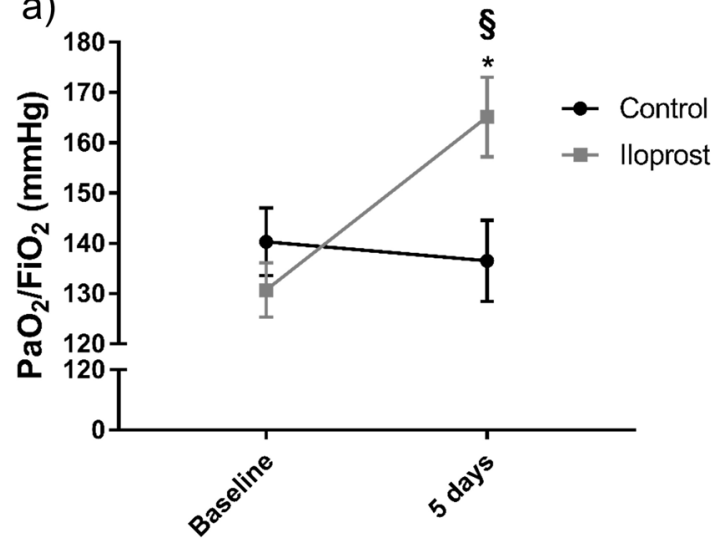

b)

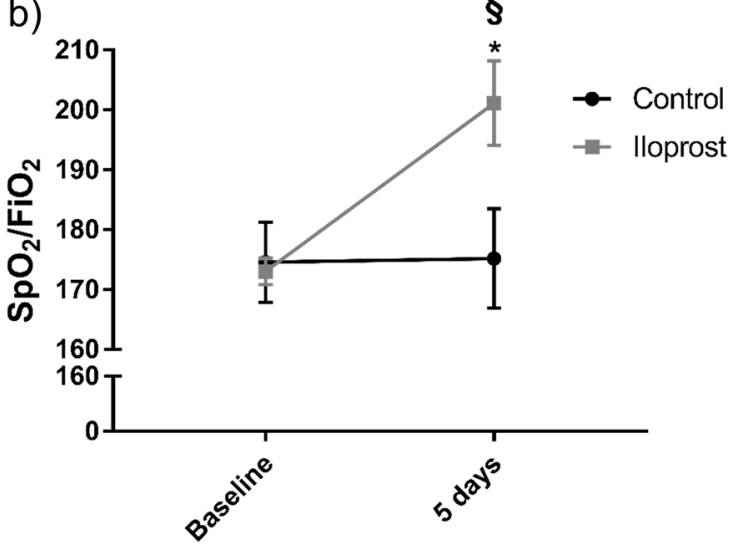

Fig. 1 Effects of inhaled iloprost on oxygenation parameters a $\mathrm{PaO}_{2} / \mathrm{FiO}_{2} ; \mathbf{b} \mathrm{SpO}_{2} / \mathrm{FiO}_{2}$ ). Results are presented as mean $\pm \mathrm{SEM}$ ( $n=16-23$ ). PaO $/$ $\mathrm{FiO}_{2}$ arterial oxygen tension-to-inspired oxygen fraction ratio, $\mathrm{SpO}_{2} / \mathrm{FiO}_{2}$ arterial oxygen saturation-to-inspired oxygen fraction ratio. Variables were compared with two-way ANOVA with Sidak's multiple comparisons test. ${ }^{*} p<0.05$. *Baseline versus 5 days; ${ }^{\S} \mathrm{Control}$ versus iloprost

our findings revealed promising effects of inhaled iloprost with improved oxygenation parameters in patients with COVID-19-associated ARDS. It must be noted that our small pilot study is hypothesis generating rather than confirmatory and its results should be proved in randomized controlled trials.

\section{Abbreviations}

ARDS: Acute respiratory distress syndrome; ICU: Intensive care unit; $\mathrm{PaO}_{2}$ : Partial pressure of oxygen; $\mathrm{FiO}_{2}$ : Fraction of inspired oxygen; $\mathrm{SpO}_{2}$ : Oxygen saturation; NEWS-2: National Early Warning Score; AE: Adverse events.

\section{Acknowledgements}

None.

\section{Authors' contributions}

SNA took part in concept and design of the study, and drafting of the manuscript; DK was involved in supervision and drafting of the manuscript; NAT, NVT and GVN took the measurements and collected the data; RTS had contributed to significant intellectual content. All authors were involved in data analysis and interpretation. Finally, all authors were involved in writing, reviewing and editing of the manuscript. All authors read and approved the final manuscript.

\section{Funding}

None.

\section{Availability of data and materials}

Data and materials can be obtained from the corresponding author upon the reasonable request.

\section{Declarations}

\section{Ethics approval and consent to participate}

The local ethics committee (LEC No. 05-20) approved the study, and written informed consent was obtained from all patients.

\section{Consent for publication}

Not applicable.

\section{Author details}

${ }^{1}$ Department of Pulmonology, I.M. Sechenov First Moscow State Medical University (Sechenov University), Healthcare Ministry of Russia, Trubetskaya Street 8, Moscow, Russia 119991. 2 Department of Internal Medicine, Justus-Liebig University Giessen, Member of the German Center for Lung Research (DZL), Giessen, Germany.

Received: 8 July 2021 Accepted: 10 July 2021

Published online: 21 July 2021

\section{References}

1. Guan WJ, Ni ZY, Hu Y, Liang WH, Ou CQ, He JX, et al, China Medical Treatment Expert Group for C. Clinical characteristics of coronavirus disease 2019 in China. N Engl J Med 2020;382:1708-20. https://doi.org/ 10.1056/NEJMoa2002032.

2. Johansson PI, Bestle M, Soe-Jensen P, Kristiansen KT, Stensballe J, Clausen NE, Perner A. The effect of prostacyclin (lloprost) infusion at a dose of $1 \mathrm{ng} / \mathrm{kg} / \mathrm{min}$ for 72 hours compared to placebo in mechanically ventilated patients with COVID-19: a structured summary of a study protocol for a randomized controlled trial. Trials. 2020;21:746. https://doi.org/10.1186/s13063-020-04696-2.

3. Moezinia CJ, Ji-Xu A, Azari A, Horlick S, Denton C, Stratton R. Iloprost for COVID-19-related vasculopathy. Lancet Rheumatol. 2020;2:e582-3. https://doi.org/10.1016/S2665-9913(20)30232-0.

4. Olschewski H, Simonneau G, Galie N, Higenbottam T, Naeije R, Rubin LJ, et al, Aerosolized Iloprost Randomized Study Group. Inhaled iloprost for severe pulmonary hypertension. N Engl J Med 2002;347:322-9. https://doi.org/10.1056/NEJMoa020204.

5. Definition Task Force ARDS, Ranieri VM, Rubenfeld GD, Thompson BT, Ferguson ND, Caldwell E, Fan E, et al. Acute respiratory distress syndrome: the Berlin definition. JAMA. 2012;307:2526-33. https://doi.org/ 10.1001/jama.2012.5669.

6. Yuan M, Yin W, Tao Z, Tan W, Hu Y. Association of radiologic findings with mortality of patients infected with 2019 novel coronavirus in Wuhan, China. PLoS ONE. 2020;15:e0230548. https://doi.org/10.1371/ journal.pone.0230548.

\section{Publisher's Note}

Springer Nature remains neutral with regard to jurisdictional claims in published maps and institutional affiliations.

\section{Competing interests}

The authors declare that they have no competing interests. 